ENTREPRENEURSHIP AND SUSTAINABILITY ISSUES

ISSN 2345-0282 (online) http://jssidoi.org/jesi/

2021 Volume 8 Number 3 (March)

http://doi.org/10.9770/jesi.2021.8.3(25)

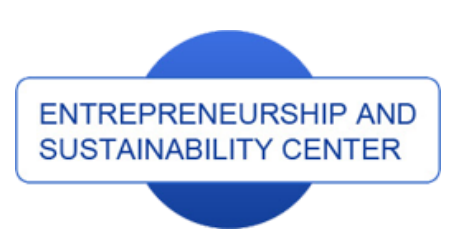

Publisher

http://jssidoi.org/esc/home

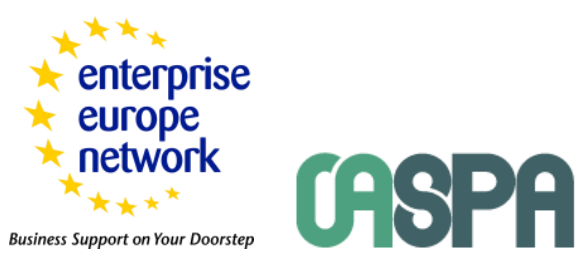

Business Support on Your Doorstep
1 Clarivate

Analytics

\title{
SMUGGLING AS A THREAT TO ECONOMIC SECURITY OF THE STATE
}

\author{
Anatolii Kulish ${ }^{1}$, Oleksandr Yunin ${ }^{2}$, Olha Us ${ }^{3}$, Iryna Shapovalova ${ }^{4}$, Ivan Yaromii ${ }^{5}$ \\ I*Sumy State University, 2 Rimsky-Korsakova Street, Sumy, 40000, Ukraine \\ ${ }^{2,5}$ Dnipropetrovsk State University of Internal Affairs, Ave. Gagarina, 26, 49005, Dnipro, Ukraine \\ ${ }^{3}$ Yaroslav Mudryi National Law University, 77 Pushkinskaya Street, Kharkiv, 61024, Ukraine \\ ${ }^{4}$ National Academy of Management, Ushynskoho str., 15, Kyiv, 03151, Ukraine \\ E-mail: ${ }^{1^{*}}$ kulish_a@ukr.net
}

Received 15 June 2020; accepted 10 January 2021; published 30 March 2021

\begin{abstract}
Smuggling has been proven to be a global threat to the economic security of each country. The authors have assessed the macroeconomic impact of smuggling on the current scale: GDP and work places. They discovered that the mechanism of administrative and legal prevention and counteraction to violations of customs rules, which is realized through the institution of administrative responsibility, appears to be independently-individual, along with other means of its legal protection. Herewith, it is worth to mention that administrative responsibility for violation of customs rules is the responsibility of a special authorized official or citizen, a regulated by the customs law norms, which resides in the awareness of guilt, illegality of actions in the area of customs legal order and, in case of sufficient grounds, ability to bear responsibility in the form of an administrative penalty, which is imposed by the customs authority or court. This shows that the object of administrative and legal prevention and counteraction to violation of the customs rules is specific and individualized. It sits in the area of social and economic relations. Administrative responsibility is an efficient means of offence prevention, including the ones, aimed at violation of the customs rules. It focuses on the prevention of any illegal behaviour. The measures of administrative prevention of the customs rules violation are characterized as the actions, applied by customs authorities, based on the provisions defined by customs legislation under the absence of customs law violations for their prevention and detection as well. They are one of the components of a complex mechanism used by the customs authorities to combat violation of the customs rules. They precede greater legal restrictions on the material and personal sphere of the offender's personality, measures of administrative termination and responsibility.
\end{abstract}

Keywords: economic security; multiplier; smuggling schemes; administrative responsibility; customs rules

Reference to this paper should be made as follows: Kulish, A., Yunin, O., Us, O., Shapovalova, I., Yaromii, I. 2021. Smuggling as a threat to economic security of the state. Entrepreneurship and Sustainability Issues, 8(3), 384-399. http://doi.org/10.9770/jesi.2021.8.3(25)

JEL Classifications: F35, F42 
ENTREPRENEURSHIP AND SUSTAINABILITY ISSUES

ISSN 2345-0282 (online) http://jssidoi.org/jesi/

2021 Volume 8 Number 3 (March)

http://doi.org/10.9770/jesi.2021.8.3(25)

Make your research more visible, join the Twitter account of ENTREPRENEURSHIP AND SUSTAINABILITY ISSUES: @Entrepr69728810

\section{Introduction}

Economic security of a country is determined by a wide array of factors (e.g. Masood et al. 2020; Chehabeddine, Tvaronavičienè, 2020).

The problem of smuggling is one of the country's major priorities in protecting its economic security. A significant part of the export-import trade flows in Ukraine are characterized as smuggled for more than two last decades. Special hazard for the state resides in the fact that smuggling operations usually involve acts of corruption, carried out by state and local authority officers. As a result, the interests of the domestic commodity producers experience significant losses.

Illegal entry of foreign goods reduces the demand for Ukrainian products, leads to liquidation of manufacturing facilities, decrease in the competitiveness of the Ukrainian enterprises in the domestic market, and their shift abroad. All those issues contribute to the reduction of personnel and wages funds.

Furthermore, the results of such criminal activity negatively affect public relations in the field of protection of life and health of citizens in case of smuggling of arms and ammunition, nuclear materials and substances, deprive the citizens of the right to use cultural values and historical heritage of Ukraine.

Smuggling should be considered to be one of the biggest threats to the national security of Ukraine. The mentioned threat reinforces itself through the policy of transnational corporations and criminal organizations, aimed at taking advantage of the criminal schemes in international economic activity, due to which the majority of financial flows remain untaxed and contribute to a significant expansion of the shadow economy.

In 2018, the legal foreign trade turnover of Ukraine amounted to $\$ 104.5$ billion, which is equivalent to $80 \%$ of the GDP of Ukraine, while shade import traditionally falls in the range of $10 \%$ from the GDP. The budget income from international commerce is generated not only by the customs fees (UAH 27.1 billion or 3\% of state budget revenues in 2018) but by the import VAT, generating significant income to the budget of Ukraine (Official site of the State Fiscal Service of Ukraine). In 2018, UAH 295.4 billion, or 79\%, out of UAH 374 billion of income from the value-added taxes, was generated thanks to import VAT. Along with customs fees and import taxes, it is $40.2 \%$, or almost a half, of state budget income.

\section{Literature Survey}

Modern juridical science offers us with a range of different grounds for classification of offences, but when it comes to characteristics of the customs offences, it seems to be appropriate to consider the classification, depending on the branch of law, the rules of which are violated in the process of the offence commitment. In this context, based on this classification basis, it is possible to identify customs offences as the ones, which trespass on a specific group of social relations, appearing in the area of state customs policy and customs affairs of Ukraine.

Upon the general rule, an offence has the following characteristics:

1) it has lawless and legally inappropriate nature, i.e. contradicts the rules of law, manifests itself as the violation of prohibitions, determined in the laws and sub-decrees, abuse of subjective law, and excess of competence (Avdeev et. al. (2019));

2) it has a socially harmful or socially dangerous nature (Danijela (2016)). The given feature is characterized by undesirability for a society, a state or an individual; it includes the appearance of the negative consequences that may occur both at the time and in the future; the degree of its danger or harm for the public may vary, and it finds its reflection in the negative reaction from the state and in accordance with the requirements of the legal norm. 


\section{ENTREPRENEURSHIP AND SUSTAINABILITY ISSUES}

ISSN 2345-0282 (online) http://jssidoi.org/jesi/

2021 Volume 8 Number 3 (March)

http://doi.org/10.9770/jesi.2021.8.3(25)

Make your research more visible, join the Twitter account of ENTREPRENEURSHIP AND SUSTAINABILITY ISSUES: @Entrepr69728810

A range of authors distinguish two aspects of public danger: first of all, it is the nature of public danger as a qualitative estimate of the harmful nature of an act, grounding on the object of the offence (Grotteli, M. (2015)); secondly, it is the degree of social danger, i.e. the size of damage caused by the offence (Kiyanchuk, I. (2017)).

The scientists consider that all offences are harmful to a society, but only a part of them are socially dangerous; 1) expressed as behaviour in the form of action (theft, robbery) or inaction (leaving a person in a helpless state). The current legislation does not consider thoughts, intentions, and beliefs to be illegal if they were not implemented (van Engelenburg, S., Janssen, M., \& Klievink, B. (2019));

2) having volitional nature, i.e. the ones, which depend on the will and consciousness of the participants at the time of execution; they are carried out voluntarily by people (Nguyen, T. C. N., Kettle, M., \& Doherty, C. (2019));

3) regarded as guilt-inducing action. Guilt is a person's mental attitude to his action and its consequences (Kormych, B. (2018));

4) has a causal connection between the action and caused consequences (Rogers, T. W., Jaccard, N., Morton, E. J., \& Griffin, L. D. (2017));

5) causes the application of legal responsibility measures to the law-breaker (Nowak, T., Sowiński, C., \& Czyźowicz, W. (2015)).

Previously, the legal literature had already formulated a position, the supporters of which stated that the range of customs offences included such tortious acts as customs offences, violation of customs rules and violations, interfering with the performance of the powers, assigned to officers of revenue and tallage bodies (Świerczyńska, J. (2016)).

Nonetheless, they provided no sufficiently strong argumentation. At the time when there are no questions to the identification of crimes, the identification of two separate groups of offences appears to be not so clear. In this context, it is logical to consider the relationship between violation of customs rules and violations, which prevent the implementation of powers, assigned to the officials of the revenue and tallage bodies with such a misdemeanour as an administrative offence.

In the course of further investigation, we think it necessary to carry out the division of the customs offence into specific groups. Based on general offence classification upon the degree of social danger and caused damage, they fall into the following categories:

- offences, illegal, guilt-inducing (intentional or unintended) action or inactivity, infringing on civil order, property, rights and freedoms of citizens, established administrative order, for which the law prescribes responsibility for the offence (Lay, C., \& Astrina, A. R. (2020));

- socially dangerous, guilt-inducing, illegal and criminally liable accts (action or inactivity), committed by the subject of crime (Komarov, O. (2016)).

According to the current legislation, the crimes, committed in the lines of customs, include the following criminal offences: smuggling, transfer of big quantities of goods, and cultural and historical valuables, poisonous and superpotent substances, radioactive materials, explosives, as well as arms and ammunition, special technical means of non-public information acquisition across the customs border of Ukraine, outside the customs control or with concealment from the customs control, stipulated in (Article 201 of The Criminal Code of Ukraine), and smuggling of narcotic drugs, psychotropic substances, their analogsta or precursors or counterfeited 


\section{ENTREPRENEURSHIP AND SUSTAINABILITY ISSUES}

ISSN 2345-0282 (online) http://jssidoi.org/jesi/

2021 Volume 8 Number 3 (March)

http://doi.org/10.9770/jesi.2021.8.3(25)

Make your research more visible, join the Twitter account of ENTREPRENEURSHIP AND SUSTAINABILITY ISSUES: @Entrepr69728810

pharmaceutical products (Article 305 of the Criminal Code of Ukraine).

\section{Methods}

The methodological basis of the study covers a set of methods, means and ways of scientific knowledge of the nature and content of the legal phenomena. The study included the use of both general scientific methods (observation, comparison, description, classification) to identify the regularities, which characterize the principle of legality; and special methods, more specifically: historical and legal - to study the genesis of legislation, concerning the regulation of the principle of legality and disclose the views of scientists of different times on the problems, related to the subject under the study; systemic and structural - for conceptual analysis of the principle of legality, its nature and place in the system of principles of criminal proceedings; a dogmatic method and a method of definitions analysis - for clarification and in-depth understanding of the conceptual and categorical apparatus, related to the subject of the study; analysis, synthesis, classification, and grouping - used for determining the subjects of observance and implementation of the principle of legality; comparative analysis when making a generalization of different approaches to implementation of the principle of legality during the pre-trial investigation; the logical and regulatory method and modelling - to formulate and justify the amendments to the criminal procedural legislation; sociological - to learn the opinions of the prosecution authority officers, regarding the problem of the study; statistical - to generalize the survey findings, study the criminal case files, law enforcement and court practice materials.

The normative-legal and information basis of the study included the Constitution of Ukraine, international agreements, considered indispensable by Verkhovna Rada of Ukraine, the judgments of the European Court of Human Rights, laws and by-laws of Ukraine, court practice.

The theoretical foundation of the research covered scientific papers in the area of legal theory, constitutional and international law, and the criminal procedure.

\section{Results}

Nonetheless, the analysis of the available information shows that the situation in the area of counteraction to smuggling has not changed significantly in recent years. It continues to be difficult. According to statistical data of the Security Service of Ukraine (SSU) for the first half of 2019, one detected 37 crimes under Article 201 of the Criminal Code of Ukraine and 4 crimes under Article 333 of the Criminal Code. People, suspected of committing, were reported on suspicion, while the items of offence were seized; 27 people were convicted; the customs officers seized objects of smuggling and detected violations of the customs rules for over UAH 18.6 million; they confiscated the items of smuggling and detected violations of the customs rules by court order for UAH 536.000. Due to its high profitability, the most common type of shadow business is the illegal transfer of excise goods across the customs border (tobacco products - to EU countries, alcohol and fuel - lubricating oils in Ukraine). Such movement has a pronounced regional localization. It results in committing official crimes (corruption) and economic crimes (creation of clandestine manufacturing facilities).

In the current year, according to the data by Security Service of Ukraine (SBU), it is reported that 18 criminal proceedings have been initiated against customs officials (13 of which - under the Article 368 of the Criminal Code of Ukraine), 13 - against members of the State Border Guard Service of Ukraine (STS of Ukraine), 2 against employees of regulatory authorities at the customs border. One convicted 7 officers of the State Tax Service of Ukraine, 3 - customs officers, and 1 officer of the controlling bodies at the customs border. One also fired 5 officials of the customs bodies, 8 servicemen of the State Tax Service of Ukraine, and 2 officers of controlling bodies on the customs border. In particular, it was reported that a number of heads of city and regional 


\section{ENTREPRENEURSHIP AND SUSTAINABILITY ISSUES}

ISSN 2345-0282 (online) http://jssidoi.org/jesi/

2021 Volume 8 Number 3 (March)

http://doi.org/10.9770/jesi.2021.8.3(25)

Make your research more visible, join the Twitter account of ENTREPRENEURSHIP AND SUSTAINABILITY ISSUES: @Entrepr69728810

customs received suspicions of wrongdoings. The State Bureau of Investigation carried out a pre-trial investigation into the possible complicity of customs officers of the Yagodin Volyn Customs of the State Fiscal Service of Ukraine (SFU of Ukraine) in the illegal transportation of goods with an approximate value of $\$ 550.000$ with the preliminary qualification of the crime as an abuse of power or official position, which entailed serious consequences (part 2 of the Article 364 of the Criminal Code of Ukraine).

The insufficient density of the Ukrainian border protection system has made it a transit point for drugs. Ukraine now has $409 \mathrm{~km}$ of uncontrolled border with the Russian Federation, the rest $1.300 \mathrm{~km}$ of the section, controlled to the junction of the border with Belarus. The main countries of supply of smuggled drugs today are Iran, Colombia, Moldova, Netherlands, Panama, Poland, Russia, Hungary, etc. For example, Poland is now one of the world's leaders in the production of synthetic drugs. It has quite developed economic ties with Ukraine as well as a fairly long border. Considering the geopolitical position of Ukraine, we can speak about the expansion of spheres of influence of the international drug mafia, using the territory of our state as a transport corridor for the transportation of drugs, as well as a new market for their sales.

The Internet and the global growth of technological advances such as mobile communications and the international banking system have made national borders more vulnerable. Information technologies are widely used by organized criminal groups as a means of preparation and implementation of smuggling. The latest information technologies provide the members of a transnational criminal organization with an opportunity to ensure their anonymity in a low-risk environment, as well as attract more people into criminal activities, hiding their personalities.

Among the main factors, providing favourable conditions for smuggling are insufficient coordination of law enforcement and regulatory authorities of Ukraine with the corresponding authorities of the neighbouring countries for information exchange on countermeasures to the movement of goods beyond the customs control or with hiding from customs control. As a rule, the reason behind this is the absence of a unified database of the customs authorities of Ukraine with the customs authorities of foreign countries; assistance of the officials of the state authorities, in particular, law enforcement and controlling ones to legal entities or individuals in the movement of the specified type of goods across the customs border of Ukraine (corruption component); imperfect and contradictory legislative regulation of the activity concerning counteraction to smuggling and violation of the customs rules; the availability of a significant difference between the prices for the specific group of goods in the domestic and international markets; unemployment of residents of the border areas.

Here are the determining factors, affecting the formation and development of the smuggling environment:

- incompleteness of the demarcation process with Russia, Belarus, and Moldova, location of settlements, private houses, territories of private property, and the land shares close to the state border line;

- insufficiency of engineering and technical arrangements of the state border line, the availability of uncontrolled roads and water crossings, significant distances between individual Ukrainian and adjacent border crossing points; - the loss of control over the specific area of a state border on the temporarily occupied territories of Ukraine, which can be used for the illegal transfer of items of crime;

- problems of personnel and logistics support of the State Tax Service of Ukraine, the customs offices of the Ukrainian Federal Customs Service, and other state bodies, performing control functions at the state border;

- corruption of the customs and border guards officers, the law enforcement officials who provide the pre-trial investigation of the criminal smuggling proceedings, as well as the corruption of the judges in sentencing smugglers;

- the insufficient level of the customs control over the international parcels due to their significant quantity; 


\section{ENTREPRENEURSHIP AND SUSTAINABILITY ISSUES}

ISSN 2345-0282 (online) http://jssidoi.org/jesi/

2021 Volume 8 Number 3 (March)

http://doi.org/10.9770/jesi.2021.8.3(25)

Make your research more visible, join the Twitter account of ENTREPRENEURSHIP AND SUSTAINABILITY ISSUES: @Entrepr69728810

- the possibility of selling smuggling goods anonymously through the Internet shops and auctions;

- gradual restriction of the powers of the law enforcement agencies in the area of counteraction to smuggling and offences of the foreign economic entities and foreign business entities;

- the absence of a clear definition of a concept and a full list of potent and toxic substances in current legislation, and the inability to conduct laboratory tests for determining a substance as poisonous or strongly active, which makes it difficult to document their smuggling.

As of today, the most common schemes for smuggling of goods include: import of goods without customs documents, payment of fees and taxes, fixation in the accounts of the corresponding services; transfer of goods by substitution or fabrication of the shipping documents, concealment of goods as other products, manipulations with the name and coding of goods, their quantity and weight; addressing of import goods to the non-existent companies; transfer of cargo beyond the checkpoints in the "green" section of the border; registration of vehicles with goods as such, which run as "empty;" "interrupted" transit (goods are declared as "transit" when imported into Ukraine with their subsequent unloading on the territory of Ukraine and formal closure of the "transit"); substitution of goods after their import into the customs territory of Ukraine on the way to the internal customs of destination; disappearance of goods that are not released into free circulation and are under customs control, from the places of their storage (warehouses and temporary storage places, territories of ports and airports).

This range also includes the abuse of the benefits, provided by legislation for the import of goods by citizens (products worth 500 euros - by road transport, 1000 euros - by air): division of big amounts of goods, formation of brigades of individual citizens (the so-called "ants"), which, within the norm "up to 500 euros, up to $50 \mathrm{~kg}$ " can move goods without taxation; "postal smuggling" - a separate direction of schemes with the norms of tax-free import (goods for the amount of no more than 150 euros in one parcel): redesign of commercial batches so that they look as small parcels, their division upon the norm of up to 150 euros and subsequent import to counterfeiters; misleading declaration: undervaluation of weight; artificial undervaluation of the customs value to border indicatives; indication of the wrong commodity code, belonging to other product; the use of goods of the "cover" group (high-cost goods are declared as low-cost, complete replacement of the names; hiding the quantitative and qualitative characteristics of goods, trademarks, and manufacturers of goods, and creation of importing firms that receive "special conditions" from the customs). (tariffs, "play" with weight and codes, etc.) for large-scale import of highly liquid imported goods, which puts the legal business in an uncompetitive environment.

After discussion of the legal aspects of the smuggling consequences as a threat to Ukrainian national security, let us consider the macroeconomic consequences of the existence of smuggling in the current scale: GDP and work places.

Figure 1 displays the methodology, compiled by the author, for assessment of the macroeconomic consequences of smuggling existence in the current scale: GDP and work places. 
Make your research more visible, join the Twitter account of ENTREPRENEURSHIP AND SUSTAINABILITY ISSUES: @Entrepr69728810

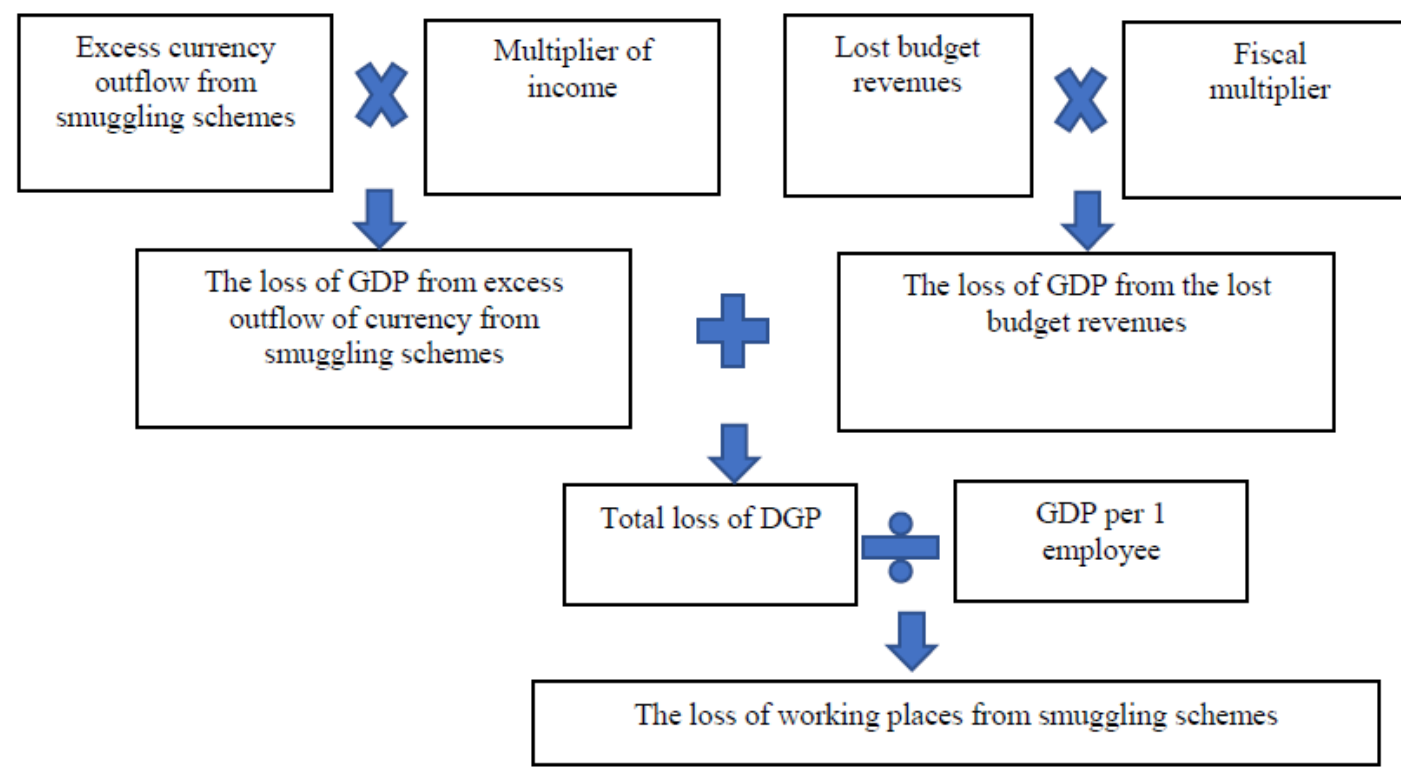

Figure 1. Architectonics of methodology for the assessment of the macroeconomic consequences of smuggling existence in the current scale: GDP and work places

Source: compiled by the authors

As for calculations, we consider it to be correct to proceed from the category of excessive outflow of currency due to the existence of smuggling schemes as even with complete "whitewashing," smuggling costs are transformed into a legal import. Nonetheless, under such a scenario, the price for imported goods will significantly increase, hence, the demand for them and the outflow of foreign currency abroad will decrease, and a significant component of the price - the tax burden - will be a flow of funds within the country. We used the following formula to calculate the excess outflow of currency:

$$
C_{v}=C_{c u r}-B_{p}+F
$$

where $C_{v}$ - excess currency outflow from smuggling, money units; $C_{c u r}$ - current volumes of incoming smuggling, money units; $B_{p}$ - new expenses of people for "whitewashing," money units; $F-\operatorname{tax}$ component (budget revenues), money units.

The current outflow of currency represents a calculated amount of smuggling. A potential outflow of currency was modelled using econometric regression.

First of all, we calculated the dependence of smuggling on the average wages in the US dollars as the one, which best represents the dynamics of consumer purchasing power in relation to import. Thus, we receive the following regression:

$$
C=1,97+0,03 \times \bar{W} ; R^{2}=97.21 \%
$$

where $C$ - volumes of smuggling, money units; $\bar{W}$ - average wages, money units. 
Make your research more visible, join the Twitter account of ENTREPRENEURSHIP AND SUSTAINABILITY ISSUES: @Entrepr69728810

Considering that current weighted-average tax burden on legal imports is $30.37 \%$, and the cost of smuggling transshipment does not exceed 7\%, after "whitewashing" smuggled goods will increase in price by an average of $21.8 \%$ (Table 1).

Table 1. Current volumes of smuggling and new expenses of customers for import by imitation of its growing price on net value of legalization in $21.8 \%$ in Ukraine (bln US dollars)

\begin{tabular}{|c|c|c|c|c|c|c|c|c|c|}
\hline Values & 2013 & 2014 & 2015 & 2016 & 2017 & 2018 & 2019 & $2020 \mathrm{~F}$ & $2021 \mathrm{~F}$ \\
\hline $\begin{array}{c}\text { Current } \\
\text { volumes of } \\
\text { smuggling }\end{array}$ & 15.3 & 10.3 & 8.0 & 8.9 & 10. & 11.9 & 13.5 & 15.4 & 17.2 \\
\hline $\begin{array}{c}\text { New expenses } \\
\text { of customers } \\
\text { for import by } \\
\text { "whitewashing" } \\
\text { of smuggled } \\
\text { goods }\end{array}$ & 12.5 & 9.5 & 6.9 & 7.2 & 8.9 & 10.4 & 10.7 & 11.9 & 13 \\
\hline
\end{tabular}

Note: F - forecast

Source: compiled by the author based on the data of Official site of the State Fiscal Service of Ukraine

Respectively, we discount the wages by the value of potential appreciation (simulating a decrease in the purchasing power of the population) and put it into the regression equation, and get the value of new potential foreign exchange expenditures of the population of Ukraine in case of smuggling schemes closure.

Alongside this, the data, obtained of the new potential expenses of the population on already "white" import include taxes, which remain inside the country and manifest themselves as an internal flow (Table 2). Therefore, for further calculations, it will be correct to use the volumes of currency, leaving the country. Respectively, we will reduce the calculated new expenditures of the population on the total tax burden of imports $-30.37 \%$. As a result, we will obtain a key indicator of indirect losses from the existence of smuggling schemes - the net surplus outflow of currency.

Table 2. Net outflow of currency as a result of the existence of smuggling schemes in Ukraine (bln US dollars)

\begin{tabular}{|c|c|c|c|c|c|c|c|c|c|}
\hline Values & 2013 & 2014 & 2015 & 2016 & 2017 & 2018 & 2019 & $2020 \mathrm{~F}$ & $2021 \mathrm{~F}$ \\
\hline $\begin{array}{c}\text { Final difference } \\
\text { in currency } \\
\text { expenses of the } \\
\text { economy }\end{array}$ & 6.6 & 3.7 & 3.2 & 3.9 & 4.2 & 4.7 & 6.0 & 7.0 & 8.2 \\
\hline
\end{tabular}

Source: compiled by the author based on the data of Official site of the State Fiscal Service of Ukraine

The next step includes consideration of the income multiplier (the average for 2013-2019 is 1.5). It is also important to increase in the corresponding proportions the indirect losses of the economy due to currency outflows and, respectively, the decline in domestic demand (Table 3).

Table 3. Total GDP losses due to excess currency outflows due to the existence of smuggling schemes in Ukraine (bln US dollars)

\begin{tabular}{|c|c|c|c|c|c|c|c|c|c|}
\hline Values & 2013 & 2014 & 2015 & 2016 & 2017 & 2018 & 2019 & $2020 \mathrm{~F}$ & $2021 \mathrm{~F}$ \\
\hline $\begin{array}{c}\text { Loss of GDP from } \\
\text { excess currency } \\
\text { outflow }\end{array}$ & 9.9 & 5.6 & 4.8 & 5.8 & 6.2 & 7.0 & 9.0 & 10.6 & 12.2 \\
\hline
\end{tabular}

Source: compiled by the author based on the data of Official site of the State Fiscal Service of Ukraine 
Make your research more visible, join the Twitter account of ENTREPRENEURSHIP AND SUSTAINABILITY ISSUES: @Entrepr69728810

While calculating the total direct and indirect losses of the economy from smuggling, it is also important to consider the lost budget revenues. Let us find them as potential expenses for legalized import, multiplied by the total tax burden of imports $-30.37 \%$ (Table 4).

Table 4. General direct and indirect losses of GDP due to the existence of smuggling schemes in Ukraine, bln US dollars

\begin{tabular}{|c|c|c|c|c|c|c|c|c|c|}
\hline Values & 2013 & 2014 & 2015 & 2016 & 2017 & 2018 & 2019 & $2020 \mathrm{~F}$ & $2021 \mathrm{~F}$ \\
\hline $\begin{array}{c}\text { Excess } \\
\text { currency } \\
\text { outflow }\end{array}$ & 9.9 & 5.6 & 4.8 & 5.8 & 6.2 & 7.0 & 9.0 & 10.6 & 12.2 \\
\hline $\begin{array}{c}\text { Loses of } \\
\text { budget }\end{array}$ & 3.8 & 2.9 & 2.1 & 22 & 2.7 & 3.2 & 3.2 & 3.6 & 3.9 \\
\hline Total & 13.7 & 8.5 & 6.9 & 8.0 & 8.9 & 10.2 & 12.2 & 14.3 & 16.2 \\
\hline
\end{tabular}

Source: compiled by the author based on the data of Official site of the State Fiscal Service of Ukraine

To calculate the loss of work places in Ukraine as a result of smuggling schemes, let us first find the current level of GDP per 1 employee, with consideration of the shadow sector. Thus, an official GDP statistic does not reflect the real added value, formed within the country. We consider the employment statistics to be correct due to the existence of significant penalties, which motivate employers to employ workers officially, at least for the minimum wage (Table 5).

Table 5. Added value, generated by one employed person in Ukraine (thousand US dollars/1 employee)

\begin{tabular}{|c|c|c|c|c|c|c|c|c|c|}
\hline Values & 2013 & 2014 & 2015 & 2016 & 2017 & 2018 & 2019 & $2020 \mathrm{~F}$ & $2021 \mathrm{~F}$ \\
\hline $\begin{array}{c}\text { GDP, bln US } \\
\text { dollars }\end{array}$ & 1465 & 2190 & 2744 & 2385 & 21984 & 3563 & 4092 & 4768 & 5454 \\
\hline $\begin{array}{c}\text { "Shade" } \\
\text { economy, \% }\end{array}$ & 35 & 43 & 40 & 35 & 35 & 32 & 32 & 32 & 32 \\
\hline $\begin{array}{l}\text { GDP: official } \\
\text { sector + "shade" } \\
\text { sector, bln US } \\
\text { dollars } \\
\end{array}$ & 1978 & 3132 & 3842 & 3220 & 4013 & 4703 & 5402 & 6294 & 7199 \\
\hline $\begin{array}{c}\text { Number of } \\
\text { employed } \\
\text { people, thousand } \\
\text { of people }\end{array}$ & 19314 & 18073 & 16443 & 16227 & 16156 & 16002 & 16000 & 16000 & 16000 \\
\hline $\begin{array}{c}\text { GDP / } \\
1 \text { employed, } \\
\text { thousand US } \\
\text { dollars per } \\
1 \text { working } \\
\text { person } \\
\end{array}$ & 12.8 & 14.4 & 10.6 & 7.7 & 9.3 & 10.8 & 12.1 & 13.6 & 15.1 \\
\hline
\end{tabular}

Source: compiled by the author based on the data of Official site of the State Fiscal Service of Ukraine

Respectively, let us divide the total loss of GDP by the average added value, generated by one employed person and, find out that as of 2017, Ukraine had lost almost 3 million potential jobs due to ineffective anti-smuggling measures (Table 6). 
ENTREPRENEURSHIP AND SUSTAINABILITY ISSUES

ISSN 2345-0282 (online) http://jssidoi.org/jesi/

2021 Volume 8 Number 3 (March)

http://doi.org/10.9770/jesi.2021.8.3(25)

Make your research more visible, join the Twitter account of ENTREPRENEURSHIP AND SUSTAINABILITY ISSUES: @Entrepr69728810

Table 6. Number of lost / "exported" work places by Ukraine as a result of the existence of smuggling schemes in existing scales, thousand

\begin{tabular}{|c|c|c|c|c|c|c|c|c|c|}
\hline Values & 2013 & 2014 & 2015 & 2016 & 2017 & 2018 & 2019 & $2020 \mathrm{~F}$ & $2021 \mathrm{~F}$ \\
\hline $\begin{array}{c}\text { Number of lost / } \\
\text { "exported" work places }\end{array}$ & 1067 & 585 & 644 & 1029 & 956 & 940 & 1009 & 1041 & 1065 \\
\hline
\end{tabular}

Source: compiled by the author based on the data of Official site of the State Fiscal Service of Ukraine

The conducted calculations make it possible to state about the need for strengthening of measures on fighting against smuggling schemes in Ukraine as a condition of national security stability.

Respectively, there are two main problems in Ukraine, enabling the life of smuggling:

Existing gaps in legislation, which create the problem of tools absence for fighting against customs regulations violations. For example, the legislation does not provide for the mandatory sealing of vehicles and $80 \%$ of cargo transported within Ukraine is not guaranteed by the importer. As a result, one can simply substitute the cargo or "drown" it. Similarly, control over the movement of parcels from the border to sorting locations (so-called "mail smuggling") is not provided for at the regulatory level. Thus, any manipulations with cargo are possible along the way.

The non-compliance with current legislation, i.e. - corruption in the customs and border guard services. On the one hand, as the successful cases of "Naftogaz" and the "Agrarian Fund" show us - partial solution of the problem lies at the level of wages of employees of these agencies and implementation of Western standards. On the other hand, the responsibility of civil servants in these agencies with the inevitability of punishment is also important.

As for the macroeconomic effect, the real problem with smuggling resides not in the loss of the budget, but the distortion of the domestic market and the principles of competition, which primarily affects legal business. Respectively, considering the importance of the smuggling problem, it is clear that the approach to its resolving should be complex. In other words, it should cover not only strengthening/improvement of controls at customs and borders but also the closure of the gaps in the domestic market, enabling the life of smuggling schemes. One of such gaps is the right of subjects of the simplified taxation system to sell goods without any primary documentation for them. That is, without documents, describing the origin of goods. Of course, smuggled goods can be sold through the "bought" necessary documents in the FSB of Ukraine, but such a scheme is already criminally punishable, much more risky and expensive. At the same time, the mass "sales" of fake primary documents by the Fiscal Service is impossible under the current institutional framework; the National AntiCorruption Bureau (NABU), the National Agency for Prevention of Corruption (NACP), the anti-corruption prosecutor's office and investigative journalists have significantly reduced the possibility of such as maneuver.

The absence of an obligation from "STS taxpayers" to have the receipt documents for goods in a complex with the possibility to sell it without cash registers provides favourable grounds for selling any amount of smuggled goods. Respectively, as long as the sale of smuggled goods is possible due to the abuse of the simplified taxation scheme, all "STS taxpayers" will constantly found themselves under unjustified pressure from the fiscal/regulatory authorities, and understandable criticism from the side of "white" business on the general taxation system.

At the same time, it is worth to mention that on practice - the operations against the possibility of selling smuggled goods in the domestic market can have a bigger return than the new anti-corruption programs at 


\section{ENTREPRENEURSHIP AND SUSTAINABILITY ISSUES}

ISSN 2345-0282 (online) http://jssidoi.org/jesi/

2021 Volume 8 Number 3 (March)

http://doi.org/10.9770/jesi.2021.8.3(25)

Make your research more visible, join the Twitter account of ENTREPRENEURSHIP AND SUSTAINABILITY ISSUES: @Entrepr69728810

customs/border guard service. Considering that the current scale of abuse of official positions is impossible without the support of political parties, which "got" the customs in the course of inter-fractional agreements. Respectively, the measures of the government of Ukraine on real counteraction to smuggling - will face the corresponding critics of the smuggling beneficiaries, media-attacks, and blocking of decisions through the judicial system, as it currently can be observed with a competition for the position of the head of the customs service. At the same time, the transition to obligatory storage of primary documents, describing the origin of goods, will neither bring harm to honest market participants nor contribute the main beneficiaries of smuggling, as a direct threat to "business."

Special prevention of customs regulations violations includes measures that directly address the causes and conditions of customs regulations violations. Special preventive measures are divided into general and individual measures. General prevention of customs regulations violations concerns a non-personified group. The general measures of special prevention of customs rules violation should include the following ones: the actions, related to the development and introduction into practice of technical means of the customs control, introduction of the newest technologies and achievements of science and technology in the field of computerization; the actions, related to the improvement of the activity of all subjects of prevention of customs rules violation; measures, aimed at improvement of professional training, legal and general culture of the customs employees, improvement of their social and financial support; proper legal support of preventive activity of the subjects, etc. Individual prevention of crime is characterized as systematic measures of purposeful action on the legal consciousness and actions of a specific person to prevent its illegal behaviour in the future. This type of the customs rules violations prevention resides in timely identification of people, who can potentially commit a violation of customs rules; in conduction of educational impact on such individuals and their micro and macro environment, and consideration of other measures.

All this allows us to come to a conclusion that it makes sense to consider the mechanism of administrative and legal prevention and counteraction to customs rules violations through a theoretical analysis of the mechanism of administrative and legal regulation and as its integral part.

In general, the mechanism of administrative and legal prevention and counteraction to violations of the customs rules is characterized by the following peculiarities and features: it is a specific set of means (administrative and legal), the application of which is aimed at regulation of public relations in the area of prevention and counteraction to the customs rules violations; prevention of the customs rules violations is a set of measures, which are carried out by specially authorized subjects to prevent causes and conditions, promoting the breach of the customs rules and prevention of their occurrence in the future.

The administrative and legal mechanism for prevention and counteraction to violations of the customs rules includes the following elements: the norms of the administrative law; administrative-legal relations; administrative-legal methods; the procedures for the norms of administrative law implementation.

All this allows us to come to the conclusion that the administrative and legal mechanism on prevention and counteraction against customs rules violations is a dynamic set of interrelated and interacting administrative and legal measures, and the means, using which the subjects' behaviour is set according to the requirements and permits of legal norms, including three stages: the publication of legal norms, the appearance of specific rights and responsibilities, and realization of the rights and obligations by the subjects of these relations. 


\section{ENTREPRENEURSHIP AND SUSTAINABILITY ISSUES}

ISSN 2345-0282 (online) http://jssidoi.org/jesi/

2021 Volume 8 Number 3 (March)

http://doi.org/10.9770/jesi.2021.8.3(25)

Make your research more visible, join the Twitter account of ENTREPRENEURSHIP AND SUSTAINABILITY ISSUES: @Entrepr69728810

It is a complex process, covering a set of operations, aimed at organization of actions, the impact of administrative law on freedom and the behaviour of the subjects of relations on prevention of offences contributing to the appearance of legal relations. Considering this, it is possible to distinguish the following elements of the administrative and legal mechanism on prevention of customs rules violations, namely: the legal norms, established by laws and by-laws, legal relations, appearing in this area and regulated by the norms of law, as well as the actions of subjects concerning the implementation of the rights and obligations, specified by the norms of law. Thus, considering public importance of the above-highlighted problems, these days, there is a need for regulation of the forms, methods, and types of preventive activity on prevention and counteraction to customs rules violation as well as the procedure for the implementation of the preventive measures by revenue and tallage authorities at the regulatory level.

All this allows us to make a conclusion, concerning the formation of the operational priorities for prevention and counteraction to violations of the customs rules. Thus, we consider it expedient, first of all, to develop and adopt the "Regulation on the Prevention of the Customs Rules Violations." This regulation should define the legal and regulatory framework, main tasks, types, forms and mechanism of application of the main measures to prevent violations of customs rules. This regulation should clearly determine the legal and regulatory frameworks, main tasks, forms, and mechanisms of application of the main measures on the customs rules violation prevention. While developing this regulation, it is advisable to give a detailed description of the main forms, methods, and objects of individual preventive measures; determine the status and powers of subjects, authorized to implement individual preventive measures; highlight the main directions for the implementation of the preventive activity, concerning prevention and counteraction to customs rules violations and fix the main preventive measures in the Plan of Action of the State Fiscal Service.

\section{Discussion}

One of the efficient ways to strengthen the fight against the illegal import of goods into the customs territory of Ukraine is the renewal of criminal responsibility for the smuggling of goods. Since the entry into force of the Law "On Amendments to Certain Legislative Acts of Ukraine Regarding Humanization of Liability for Offences in the Sphere of Economic Activity" in the part, considering the terms of removing criminal liability for the smuggling of goods, the number of such offences has significantly increased.

The strategy, approved by Cabinet of Ministers of Ukraine (CMU), Strategy in the field of combating illicit production and circulation of tobacco products until 2021 (2017), determines illegal tobacco trade as a threat to national security, hindering the economic development of the state, and the one, having a negative impact on Ukraine's image in the international arena. One of the main directions of this strategy is the introduction of criminal responsibility for the illegal transfer of tobacco products across the customs border of Ukraine. The proposal of setting criminal responsibility for "commodity smuggling" was supported in June 2019 by the interagency working group on coordination of integrated border management (established by the Decree of the Government of Ukraine of 30.01.2019 № 83) during the consideration of the project a National Integrated Border Management Strategy for the period up to 2025.

Under such conditions, to increase the efficiency of measures on fighting against smuggling, encouraging of participants of foreign economic activity to faithful payment of the customs fees, unconditional direction to the state income of smuggled excisable and other goods; there is the need for establishing criminal liability for smuggling of excisable and counterfeit goods (products) in large amounts through the addition of the corresponding group of goods to the objects of crime, specified by the Article 201 of the Criminal Code of Ukraine. 


\section{ENTREPRENEURSHIP AND SUSTAINABILITY ISSUES}

ISSN 2345-0282 (online) http://jssidoi.org/jesi/

2021 Volume 8 Number 3 (March)

http://doi.org/10.9770/jesi.2021.8.3(25)

Make your research more visible, join the Twitter account of ENTREPRENEURSHIP AND SUSTAINABILITY ISSUES: @Entrepr69728810

Here, one should also add the need for establishing criminal liability for illegal creation and use of engineering structures and vehicles for illegal transfer of goods across the state border of Ukraine. In addition, it is advisable to initiate amendments and additions to other regulations, in particular: to define the concept and list of poisonous and potent substances; implement the provisions of the Concept of creation and implementation of the automated system of control over the circulation of excisable goods (alcoholic beverages and tobacco products) "Electronic excise stamp," approved by the resolution of the Cabinet of Ministers of Ukraine of 06.07.2016 № 497-p.

Organizational plan proposals:

1. The approach to solving the smuggling problem should be multidimensional - cover not only strengthening of customs and border controls but also include the elimination of the gaps in the internal market, which make it possible for the smuggling schemes to exist.

2. In real-world terms, the operations against the possibility of selling smuggled goods in the domestic market through the Special Operations Service has a bigger return than the new anti-corruption programs at customs and border guards.

3. The situation requires provision of full information exchange between the databases of the customs and border guard services, as well as compliance with the requirements of the law on the right of duty-free importation of goods while being abroad for more than 24 hours and entry for no more than once every 72 hours.

4. The anti-smuggling operations on detection of smuggling sources should consider a social aspect, performing law enforcement and economic functions, more precisely - promote overcoming of unemployment in the border areas.

5. The system of provision of the customs security of Ukraine should be formed with consideration of the international experience of the world's major economies. In this regard, it is necessary to reform the subjects of customs security provision in Ukraine.

6. It is necessary to broaden the powers, regarding the implementation of law enforcement intelligence-gathering activities by the customs authorities, and to unify the customs and criminal procedural legislation of Ukraine in the part, related to the provision of the efficient mechanisms for implementation law enforcement intelligencegathering activities by the customs authorities, connected to the crimes, the characteristics of which can be detected during customs control.

\section{Conclusions}

Upon the research results, it is possible to draw the following conclusions.

1. Smuggling in Ukraine has been widespread throughout all period of its independence. The results of the criminal activity of smugglers found their reflection in all spheres of economic activity of the state.

2. The highest forms of smuggling in Ukraine are one of the components of transnational organized crime activity.

3. The crimes, which are related to an illegal transfer of cargo across the border of Ukraine, are implemented through the use of the corruption schemes, including engagement of the officials of the State Fiscal Service of Ukraine and the State Border Guard Service of Ukraine, and other state bodies as well.

4. Judges in Ukraine often consciously help the criminals to avoid just punishment for crimes, related to smuggling, which can be qualified as a corruption crime.

5. One of the gaps on the internal market that contributes to smuggling is the right of entities of the simplified taxation system to sell goods without any primary documentation for them, which would describe the origin of the products. 


\section{ENTREPRENEURSHIP AND SUSTAINABILITY ISSUES}

ISSN 2345-0282 (online) http://jssidoi.org/jesi/

2021 Volume 8 Number 3 (March)

http://doi.org/10.9770/jesi.2021.8.3(25)

Make your research more visible, join the Twitter account of ENTREPRENEURSHIP AND SUSTAINABILITY ISSUES: @Entrepr69728810

6. The absence of an obligation from "STS taxpayers" to have the receipt documents for goods in a complex with the possibility to sell it without cash registers provides favourable grounds for selling any amount of smuggled goods.

7. The current scale of abuse of official positions would not have been possible without the support of political parties, which "got" the customs in the course of inter-fractional agreements.

8. The government measures on counteraction to smuggling face the corresponding critics of the smuggling beneficiaries, media-attacks, and blocking of decisions through the judicial system.

9. Smuggling also flourishes thanks to a longstanding practice of getting additional untaxed income among the residents in the border areas - smuggling acts as a "living" alternative to employment or legal entrepreneurship.

10. Rough breach of the law in the customs and State Border Guard Service of Ukraine are possible only under the condition of availability of the corresponding corruption, grounding on the breaches in the information flows with those states, which are regarded as trade partners of Ukraine.

\section{References}

Avdeev, V. A., Rozenko, S. V., Bulygin, A. V., \& Byzova, I. G. (2019). Mechanism of Customs-Legal Regulation and Ensuring Economic Security Taking into Account the Features of the Northern Region. International Journal of Civil Engineering and Technology, 10(2), 1777-1783. Available at: http://www.academia.edu/download/58606192/IJCIET1002173.pdf

Chehabeddine, M., Tvaronavičienė, M. (2020). Securing regional development. Insights into Regional Development, 2(1), 430-442. http://doi.org/10.9770/IRD.2020.2.1(3)

Danijela, M. (2016). Security roll of the Macedonian customs. European journal of law and political sciences, (4).

Grotteli, M. (2015). The safety and security of international trade as a determinant of the business strategy of the Polish Customs Service. European Integration Studies, 9(1), 139-154. Available at: $\underline{\text { https://www.ceeol.com/search/article-detail?id=478127 }}$

Kiyanchuk, I. (2017). Influence of customs payments on the economic security of the country, problems and ways of overcoming. Baltic Journal of Economic Studies, 3(3).

Komarov, O. (2016). Customs control and risk management system on the example of the Ukrainian customs. Customs Scientific Journal CUSTOMS, 6(2), 85-97.

Kormych, B. (2018). The Modern Trends of Foreign Trade Policy Implementation: Implications for Customs Regulations. Lex Portus, 13, 27. Available at: https://heinonline.org/HOL/LandingPage?handle=hein.journals/lxportus $13 \&$ div=5\&id=\&page=

Lay, C., \& Astrina, A. R. (2020). The Limits of the Multiple Institutionalization of Border Control: A Case Study of Immigration, Customs, and the Indonesian Maritime Security Agency in Batam, Indonesia. Pacific Affairs, 93(1), 113-134. Available at: https://www.ingentaconnect.com/content/paaf/paaf/2020/00000093/00000001/art00006

Masood, O., Javaria, K., Petrenko, Y. (2020). Terrorism activities influence on financial stock markets: an empirical evidence from United Kingdom, India, France, Pakistan, Spain and America. Insights into Regional Development, $2(1)$, $443-455$. https://doi.org/10.9770/IRD.2020.2.1(4)

Nguyen, T. C. N., Kettle, M., \& Doherty, C. (2019). From form to function: Mobile language resources in the Vietnamese customs setting. Journal of International and Intercultural Communication, 12(4), 344-363. Available at: https://www.tandfonline.com/doi/abs/10.1080/17513057.2019.1572208 


\section{ENTREPRENEURSHIP AND SUSTAINABILITY ISSUES}

ISSN 2345-0282 (online) http://jssidoi.org/jesi/

2021 Volume 8 Number 3 (March)

http://doi.org/10.9770/jesi.2021.8.3(25)

Make your research more visible, join the Twitter account of ENTREPRENEURSHIP AND SUSTAINABILITY ISSUES: @Entrepr69728810

Nowak, T., Sowiński, C., \& Czyźowicz, W. (2015). Customs protection of cultural property as part of the security policy of the European Union. Customs Scientific Journal CUSTOMS, 5(2), 7-16. Available at: https://www.ccjournals.eu/ojs/index.php/customs/article/view/468

Official site of the State Fiscal Service of Ukraine. Available at: http://sfs.gov.ua/diyalnist-/borotba-z-ekonomichnoyu-zlochinnisty\%20uta/informatsiya-pro-vjittya-zahodiv-schodo-bo/223549.html

On approval of the Concept of creation and implementation of the automated system of control over the circulation of excisable goods (alcoholic beverages and tobacco products) "Electronic excise stamp" (2016). Available at: https://zakon.rada.gov.ua/laws/show/497-2016p?lang=en\#Text

On approval of the Strategy in the field of combating illicit production and circulation of tobacco products until 2021 (2017). Available at: https://zakon.rada.gov.ua/laws/show/570-2017-p?lang=en\#Text

Rogers, T. W., Jaccard, N., Morton, E. J., \& Griffin, L. D. (2017). Automated x-ray image analysis for cargo security: Critical review and future promise. Journal of X-ray science and technology, 25(1), 33-56. Available at: https://content.iospress.com/articles/journal-of-x-rayscience-and-technology/xst606

Security Service of Ukraine. Available at: https://ssu.gov.ua/

Świerczyńska, J. (2016). The reduction of barriers in customs as one of the measures taken by the customs service in the proces of ensuring security and safety of trade. Studia Ekonomiczne, 266, 212-222. Available at: http://yadda.icm.edu.pl/yadda/element/bwmeta1.element.cejsh-6c221efb-5988-47aa-81e1-60f3f6d5d266

The Criminal Code of Ukraine. Available at: https://zakon.rada.gov.ua/laws/show/2341-14?lang=en\#Text

van Engelenburg, S., Janssen, M., \& Klievink, B. (2019). Design of a software architecture supporting business-to-government information sharing to improve public safety and security. Journal of Intelligent information systems, 1-24. Available at: https://link.springer.com/article/10.1007/s10844-017-0478-z 


\section{ENTREPRENEURSHIP AND SUSTAINABILITY ISSUES}

ISSN 2345-0282 (online) http://jssidoi.org/jesi/

2021 Volume 8 Number 3 (March)

http://doi.org/10.9770/jesi.2021.8.3(25)

Make your research more visible, join the Twitter account of ENTREPRENEURSHIP AND SUSTAINABILITY ISSUES: @Entrepr69728810

Anatolii KULISH, Doctor of Science of Law, Professor, Sumy State University

ORCID ID: orcid.org/0000-0003-2700-483X

Oleksandr YUNIN, Doctor of Legal Sciences, Professor, Dnipropetrovsk State University of Internal Affairs

ORCID ID: orcid.org/0000-0003-4846-2573

Olha US, Yaroslav Mudryi National Law University

ORCID ID: orcid.org/0000-0002-9035-822X

Iryna SHAPOVALOVA, Candidate of Law, Professor, National Academy of Management

ORCID ID: orcid.org/0000-0002-9145-8994

Ivan YAROMII, $\mathrm{PhD}$ in Law, Dnipropetrovsk State University of Internal Affairs

ORCID ID: orcid.org/0000-0002-0879-500X

Copyright (C) 2021 by author(s) and VsI Entrepreneurship and Sustainability Center

This work is licensed under the Creative Commons Attribution International License (CC BY).

http://creativecommons.org/licenses/by/4.0/

c) (7) Open Access 